\title{
Investigation of factors influencing on wood adhesion capability
}

\author{
Huseyin YORUR \\ Karabuk University, Faculty of Forestry, Forest Engineering Department, Karabuk, TURKEY \\ huseyinyorur@karabuk.edu.tr
}

Received Date: 25.01.2018

Accepted Date: 16.03.2018

\begin{abstract}
Aim of the study: In this study, the influencing factors on the capability of adhesion in Uludag Fir (Abies bornmülleriana Mattf.), Chestnut (Castanea sativa Mill.) and Poplar (Populus tremula L.) woods were investigated

Material and Methods: An important problem is that wood have different wettability that makes the bonding process difficult. Influence of PVAc-D3 and PU-D4 adhesives, which are widely used in the furniture industry, on wetting properties was evaluated by contact angle measurement analysis. Bonding strengths of the laminated veneers, which were untreated, treated in two hours at $-20{ }^{\circ} \mathrm{C}$ and $60{ }^{\circ} \mathrm{C}$ temperatures, water immersion, and water vapor, were determined. Influence of adhesives on the wetting properties was evaluated by contact angle measurement analysis. The adhesion line to determine wettability was investigated with scanning electron microscopy (SEM), and energy dispersive X-ray analysis (EDX).

Main results: The results indicated that bonding strength of chestnut wood was determined to be higher than poplar and Uludag fir for all applications. The results generally showed that the applied treatments were resulted in a decrease in bonding strength for both types of adhesive. The lowest bonding strength was determined when the specimens were exposed to water immersion. The results clearly indicate that the surface wettability measurements were informative for forming of adhesion layers. According to the EDX analysis, a decrease of carbon and oxygen was observed in the transition from adhesive to wood.

Research highlights: The adhesion capabilities were directly related to wood density and different treatment factors. The different wood species and adhesives used affected on wettability.
\end{abstract}

Keywords: LVL, Bonding strength, Wettability, Thermal conductivity, EDX, SEM

\section{Odunun yapışma kabiliyetini etkileyen faktörlerin incelenmesi}

Özet

Çalışmanın amacı: Bu çalışmada, uludağ göknarı (Abies bornmülleriana Mattf.), kestane (Castanea sativa Mill.) ve kavak (Populus tremula L.) odunlarında yapışma kabiliyetine etki eden faktörler araştırılmıştır.

Materyal ve Yöntem: Odunun farklı slanabilirlik özelliğe sahip olması, yapışma sürecini zorlaştıran önemli bir problemdir. Mobilya endüstrisinde yaygın olarak kullanılan PVAc-D3 ve PU-D4 yapıştırıcılarının ıslatma özellikleri temas açısı ölçümü ile değerlendirilmiştir. Lamine edilmiş kaplamalar, 2 saat süreyle $-20^{\circ} \mathrm{C}$ ve $60{ }^{\circ} \mathrm{C}$ sıcakliklarda su ve su buharında bekletme işlemlerine tabii tutulmuş ve örneklerin yapışma mukavemetleri belirlenmiştir. Ayrıca yapıştırıcıların ağaç malzemeyi sslatabilme kabiliyeti temas açısı ölçüm analizi ile değerlendirilmiştir. Islanabilirliğin belirlenmesi için yapışma hattı, taramalı elektron mikroskobu (SEM) ve enerji dağılımlı X-ı̧̧ını analizi (EDX) ile incelenmiştir.

Sonuçlar: Tüm işlemler için kestane odunun yapışma direncinin kavak ve göknar odununa göre daha yüksek olduğu belirlenmiştir. Genel olarak sonuçlar, uygulanan işlemlerin her iki yapıştırıcı tipi için yapışma direncinde bir azalmaya neden olduğunu gösterdi. En düşük yapışma direnci, suda bekletilen örneklerde belirlenmiştir. Yüzey sslanabilirlik ölçümlerinin, yapışma katmanın oluşması hakkında bilgi verici olduğu görülmüştür. EDX analizine göre, yapıştırıcıdan oduna geçişte karbon ve oksijen azalması gözlemlenmiştir.

Araştırma vurguları: Yapışma kabiliyeti doğrudan odunun yoğunluğu ve çeşitli uygulama faktörleri ile ilgili olduğu belirlenmiştir. Kullanılan farklı odun türleri ve yapıştırıcılar sslanabilme özelliğini etkiler.

Anahtar Kelimeler: LVL, Yapışma direnci, Islanabilirlilik, Isı iletkenliği, EDX, SEM 


\section{Introduction}

Wood characteristics are unusual compared to almost any other structural and engineering material. Meanwhile, increased demand for wood has caused a considerable reduction in forest resources. To meet this ever-increasing demand, it is necessary to use appropriate manufacture techniques for the best yield (Aydin et al. 2004). Because of wood material has hygroscopic and anisotropic structure, use of layered materials improve undesirable structural properties. Therefore, laminated wood and wood joints may be utilized as a substitute for solid wood as they retain the structural features of wood (Kamala et al. 1999). Veneers obtained from medium or small diameter logs can be converted into laminated wood or glued parallel laminates, which have all the features of thick wood boards (Kilic et al. 2006). Bonding strength of laminated wood and wood joints can be categorized as parameters of the bonding process, features of the resin and the adhesive mix, and woodrelated parameters (Gavrilovic-Grmusa et al. 2012). For a good adhesion capability; surface roughness and wettability of wood are very significant. The adhesive properties such as wet flow, penetration, and cure on wood surface have a significant role in the ability of an adhesive (Wang et al. 2007). Understanding of the interaction of liquids with solid substrates is important. Therefore, wettability measurements are a useful method for determining the thermodynamic behavior of wood surface because it is adhesive bonded in $70 \%$ of all applications (Gardner et al. 1991).

Wettability of wood is frequently evaluated by measuring the contact angle of a droplet on the side by evaluating its progress with respect to time (Shi and Gardner 2001). The lower the contact angle, the greater the wettability. Yorur et al. (2017) determined the effect of surface roughness on wettability of Pine, Beech and Fir using PVAc adhesive. As a result; the wetting angle is affected by the change of surface roughness. Penetration of an adhesive into the wood is an important part of the bonding process (Frihart 2005). The lumens of cells are large enough to provide a good pathway for liquid-phase resin flow. Interconnecting pits are often adequate to permit resin flow. However, high molecular weight resins or occlusions in the pits or lumens may inhibit flow (Kamke and Lee, 2007). Also, the same study states that adhesive penetration into the wood may be categorized into gross penetration which results from the flow of liquid resin into the porous structure of wood, mostly filling cell lumens, and as well as cell-wall penetration that occurs when resin diffuses into the cell wall or flows into micro fissures. The wettability can be influenced by various factors such as heterogeneity and porosity, chemical components of the wood surface, wood grain direction, extractives, acidity (Buyuksari et al. 2011). In addition, surface roughness is very important in applications such as utilization of adhesive in wood (Sulaiman et al. 2009). Smoother surfaces have higher bonding strengths compared to rougher surfaces (Buyuksari et al. 2011, Sogutlu 2017). Surface roughness values can be affected by various factors such as cross grain, rays, annual ring width mature and juvenile wood, reaction wood, ratio latewood and earlywood, knots, and specific cell structures, wood density (Dundar et al. 2008). It is assumed that these different bonding strength values of the adhesives stemmed from the differences between their technological structures, penetration of the adhesive, reaction mechanisms and adhesivecohesive bonding characteristics (Kaygin and Tankut 2008, Yorur et al. 2014).

In this study, the influencing factors on the capability of adhesion in Uludag Fir, Chestnut, and Poplar veneers were investigated. Influence of PVAc-D3 and PUD4 adhesives, which are widely used in the furniture and construction industries, on wetting properties was evaluated by contact angle measurement analysis.

\section{Material and Method Woods}

The specimens of Uludag Fir (Abies bornmülleriana Mattf.), Chestnut (Castanea sativa Mill.), and Poplar (Populus tremula L.) were chosen from non-deficient, knotless, normally grown (without zone line, without reaction wood and without insect, fungi damages) wood specimens. The wood 
specimens were obtained from Karabuk and Bartin, located at west point of the Black Sea Region in Turkey.

\section{Adhesives}

Polyvinyl Acetate (PVAc-D3) and Polyurethane-based (PU-D4) adhesives, which are usually used for the assembly process in the furniture industry, were employed. PVAc-D3 has a viscosity of $14000 \mathrm{mPa}$.s and a density of $1.05 \mathrm{~g} / \mathrm{cm}^{3}$ at $20{ }^{\circ} \mathrm{C}$ (Wurth, producer firm, 2018). PU-D4 which is described as a polyurethane-based one-component adhesive with a viscosity of $6000 \mathrm{mPa}$.s and a density of $1.10 \mathrm{~g} / \mathrm{cm}^{3}$ at 20 ${ }^{\circ} \mathrm{C}$ (Soudal, producer firm, 2018).

\section{Wettability}

PVAc-D3 and PU-D4 adhesives were dropped on wood substrate of the specimens of $50 \times 50 \times 10$ (width $\times$ length $\times$ height) $\mathrm{mm}$ at room temperatures. Dynamic contact angle measurements were conducted by Casio Pro EX-F1 (1200 fps) model camera. PVAc-D3 and PU-D4 adhesives were dropped on substrate surfaces through an adjustable injector. The views of drops were caught at the 0,5 th, 15th, 30th, 60th and 150th seconds and these images were transferred into AutoCAD 2017 to measure contact angles of each drop from the right and left profiles. These processes repeated three times and mean angle values were calculated and the diagrams were drawn through the Sigma Plot 12.0 Software (Omaç et al. 2017).

\section{Determination of Moisture Content and Density}

The moisture content of the wood specimens before bonding was determined according to TS 2471. The densities of the wood materials were determined according to TS 2472 .

\section{Bonding Strength}

Each of the specimens was subjected to the bonding test in a 5-ton universal test machine. The loading speed of the machine during the experiment was adjusted to 2 $\mathrm{mm} / \mathrm{min}$.

\section{SEM and EDX}

The SEM studies were conducted to analyze of the adhesion on cell walls. Ultrastructural observations were operated at 15 $\mathrm{Kv}$ using a Hitachi 4500 SEM (Zeiss, Munich, Germany). EDX is an X-ray technique used to identify the elemental composition of materials and this technique is non-destructive.

The bond line was analyzed by means of EDX spectroscopy to investigate distribution of adhesives within the wood. Specimens with the size of $20 \mathrm{~mm} \times 10 \mathrm{~mm} \times 10 \mathrm{~mm}$ were cut from bonded wood.

\section{Preparation of Experiment Specimens}

The wood specimens at the dimensions of $6(\mathrm{~h}) \times 100(\mathrm{w}) \times 900$ (l) $\mathrm{mm}$ were cut in tangential orientations with $3200 \mathrm{rpm}$ of a circular sawing machine. After the specimens were calibrated and prepared for the adhesion surfaces, surface roughness, and wetting. The surface roughness was measured by mean arithmetic deviation of profile (Ra) and maximum roughness (Ry) accordance with DIN 4768 standard from tangential surface of woods. A Mitutoyo SJ-310 instrument was used to measure surface roughness. The instrument has a measuring speed of 10 $\mathrm{mm} / \mathrm{min}$, a needle radius of $5 \mu \mathrm{m}$ and a $90^{\circ}$ shaft angle. The specimens were bonded with PVAc-D3 and PU-D4 adhesives. The adhesives were applied to tangential surface of veneer at a rate of $200 \mathrm{~g} / \mathrm{m}^{2}$. The specimens were compressed by using a pressure of $1.5 \mathrm{~N} / \mathrm{mm}^{2}$ for one hour at $50{ }^{\circ} \mathrm{C}$ for PVAc-D3 and two hours at $20^{\circ} \mathrm{C}$ for PUD4. A total of 300 specimens were prepared by considering three wood types, two adhesive types, five different treatments, and ten experimental trails for each laminated veneer. The laminated veneers were sized at $10 \times 20 \times 150 \mathrm{~mm}$ dimensions according to BS EN 205 standard. The test specimens were kept two hours at $-20{ }^{\circ} \mathrm{C}$ and $60{ }^{\circ} \mathrm{C}$ temperatures, water immersion, and water vapor at $50{ }^{\circ} \mathrm{C}$ to determine bonding performance under different ambient conditions. After that, they were tested on a Universal Test Machine. The thermal conductivity of solid wood and laminated veneer specimens was measured by a quick thermal conductivity meter according to 
ASTM C 1113-99 hot-wire method by QTM 500 meter.

\section{Results and Discussion}

The main objective of this study was to examine the relation between the adhesives and the wood species. The major findings obtained were explained in detail with respect to density, moisture content (MC), wettability, surface roughness, thermal conductivity, bonding strength.

\section{Density}

The density changes after treatment were measured for all wood specimens as shown in Table 1. density of a wood is mainly related to porosity, cell wall thickness, etc. The density affects many factors such as, surface roughness, wettability, adhesion and strength.

When the average values of density were compared, the highest density $(0.751 \mathrm{~g} / \mathrm{cm} 3)$ was found in Chestnut samples, while the lowest density of the oven-dried group was observed in the Poplar samples $(0.328$ $\mathrm{g} / \mathrm{cm} 3$ ). Density is one of the main character traits for wood. But, the amount of shrinking and swelling with changes in moisture content is also an important factor where long-term serviceability of glue joints are in particular, required (Selbo, 1975). MC in the structure of wood can affect the bonding strength to structure of the adhesives (Uysal and Kurt 2005). The optimum moisture content in the wood is about 6-12\% for good adhesion (Kaya 1977).

\section{Wettability}

Wettability is closely related to hydrophilicity. Also, Penetration ability is directly related to wettability. Adhesives penetrate in the wood. Therefore, it is more important wettability for adhesion line. In the study, the wettability of wood surfaces was examined by sessile drop technique. The relationship between the time-dependent behaviors of a drop for wood substrates was depicted in Fig. 1 and also Fig. 2 showed contact angles of adhesives.

Table 1. Density values of wood species based on treatments $\left[\mathrm{gr} / \mathrm{cm}^{3}\right]$

\begin{tabular}{|c|c|c|c|c|c|c|c|}
\hline Wood type & $\mathrm{MC}[\%]$ & $\begin{array}{l}\text { Oven-dry } \\
\text { density }\end{array}$ & $\begin{array}{l}\text { Air-dry } \\
\text { density }\end{array}$ & $-20{ }^{\circ} \mathrm{C}$ & $60{ }^{\circ} \mathrm{C}$ & $\begin{array}{l}\text { Water } \\
\text { immersion }\end{array}$ & $\begin{array}{l}\text { Water } \\
\text { vapor }\end{array}$ \\
\hline Uludag Fir & 10.6 & $\begin{array}{l}0.401 \\
(0.01)\end{array}$ & $\begin{array}{l}0.460 \\
(0.02)\end{array}$ & $\begin{array}{l}0.510 \\
(0.06)\end{array}$ & $\begin{array}{l}0.430 \\
(0.01)\end{array}$ & $\begin{array}{l}0.730 \\
(0.15)\end{array}$ & $\begin{array}{l}0.675 \\
(0.07)\end{array}$ \\
\hline Chestnut & 10.6 & $\begin{array}{l}0.477 \\
(0.01)\end{array}$ & $\begin{array}{l}0.534 \\
(0.01)\end{array}$ & $\begin{array}{l}0.549 \\
(0.08)\end{array}$ & $\begin{array}{l}0.522 \\
(0.01)\end{array}$ & $\begin{array}{l}0.751 \\
(0.14)\end{array}$ & $\begin{array}{l}0.576 \\
(0.09)\end{array}$ \\
\hline Poplar & 10.5 & $\begin{array}{l}0.328 \\
(0.04)\end{array}$ & $\begin{array}{l}0.339 \\
(0.02)\end{array}$ & $\begin{array}{l}0.355 \\
(0.04)\end{array}$ & $\begin{array}{l}0.333 \\
(0.01)\end{array}$ & $\begin{array}{l}0.656 \\
(0.23)\end{array}$ & $\begin{array}{l}0.519 \\
(0.11)\end{array}$ \\
\hline
\end{tabular}

* Values in parentheses are standard deviations. 


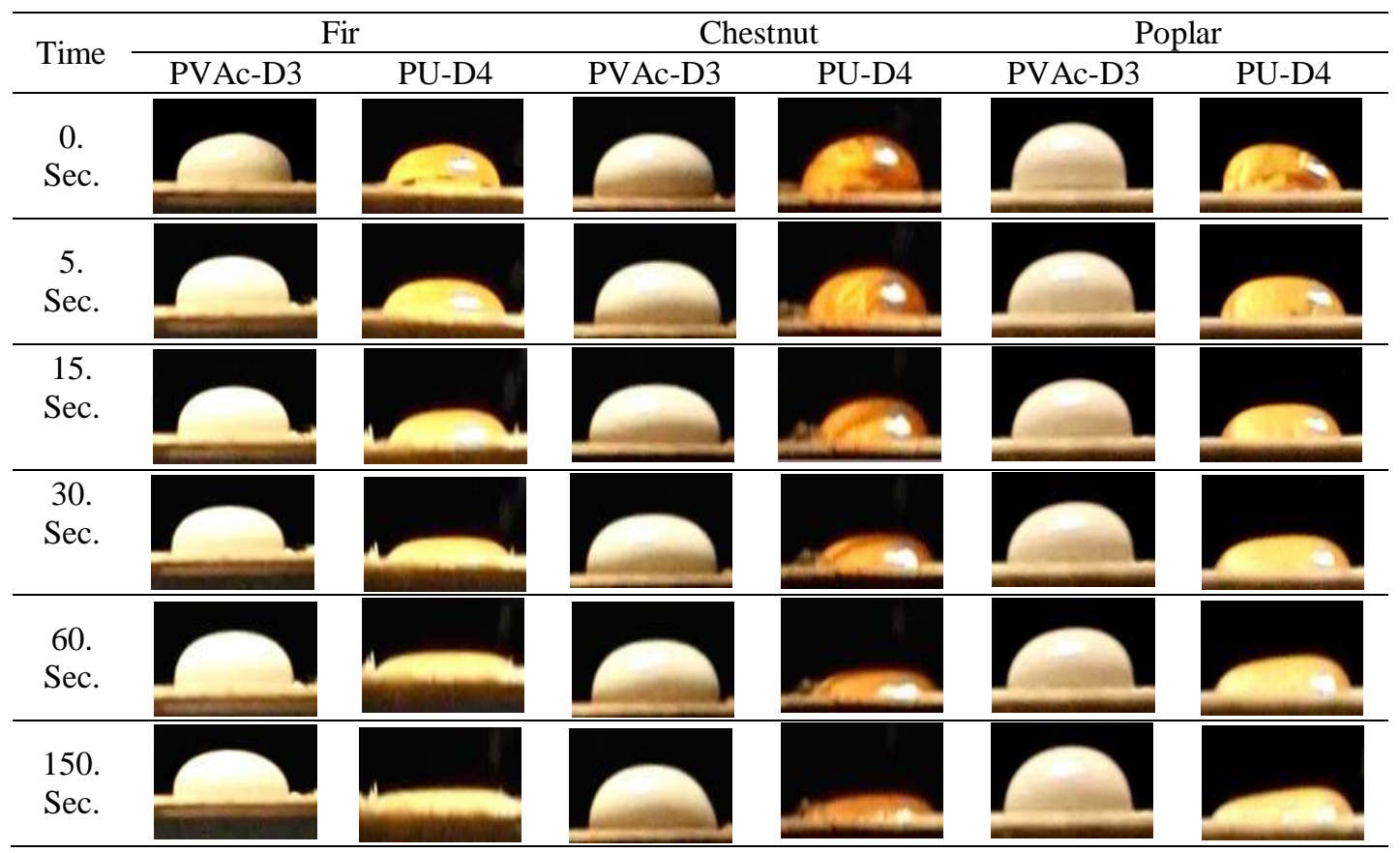

Figure 1. Time-dependent drops of PVAc-D3 and PU-D4 adhesives on Fir, Chestnut and Poplar wood substrates

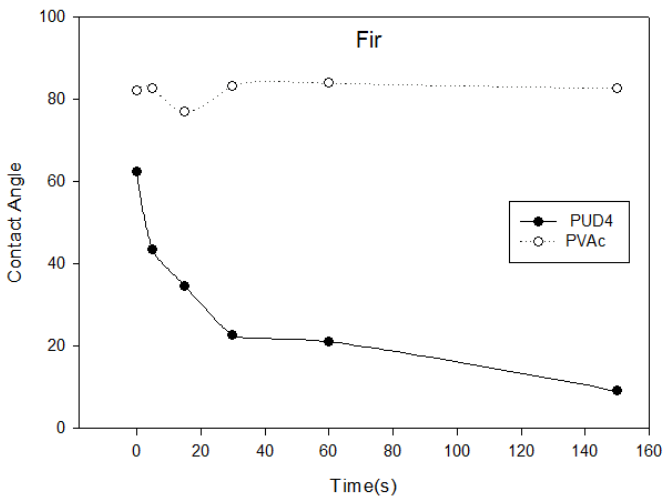

(a)

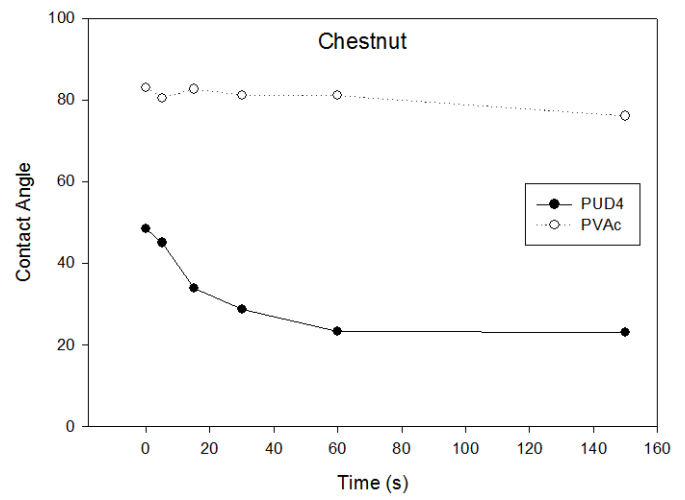

(b)

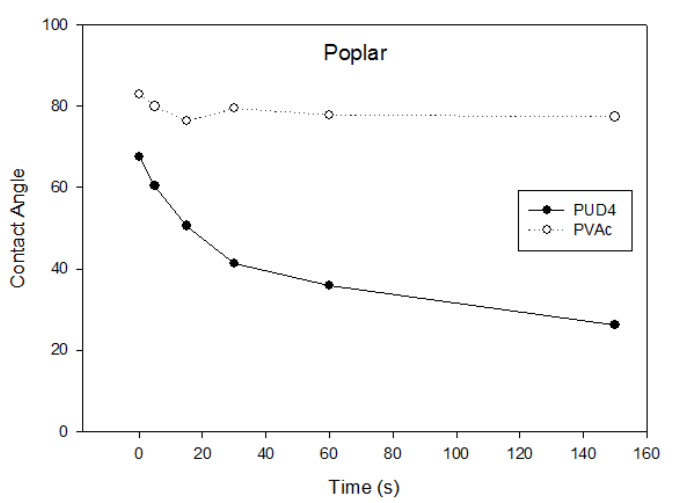

(c) 
Figure 2. Contact angles of adhesives for Fir (a) Chestnut (b), and Poplar (c)

Influence of adhesives on the wetting properties was evaluated by contact angle measurement analysis. As it can be seen in Fig 1, the measured contact angle values were affected by the wood density and adhesive. The contact angles of PVAc-D3 and PU-D4 adhesives for the ranges of $0-150$ sec. were given in in Fig. 2.

The relationship between the contact angle and the time was given in Fig. 2. A sharp decrease in the contact angle of PU-D4 was observed for approximately at the first $30 \mathrm{~s}$ for all wood specimens. For PVAc-D3 adhesive, the contact angle decreases suddenly at about $10 \mathrm{~s}$, but the adhesives were almost regained the initial form due to the high cohesive force of adhesives. At a low wetting velocity, the roughness of a hydrophilic surface enhances the wetting process. As the wetting velocity increases to a critical value, the surface roughness starts to inhibit wetting (Zhao et al. 2014). So, the wettability has deteriorated with increasing surface roughness.

\section{Bonding Strength}

The Average bonding strength values, surface roughness and thermal conductivity of control specimens and laminated veneers based on the different treatments are given in Table 2. The higher bonding strength was determined at Chestnut specimens in comparison to Poplar and Fir. When the adhesive types after treatment are compared the bonding strength of PVAc-D3 was higher than of PU-D4 except for the specimens treated with water immersion and water vapor. PU-D4 gave better results at water immersion and water vapor treatments. According to the control samples, it can be said that the temperatures of $-20{ }^{\circ} \mathrm{C}$ and 60 ${ }^{\circ} \mathrm{C}$, water immersion and water vapor treatments were decreased the bonding strength.

Table 2. Average values of bonding strength of control and different treatment specimens.

\begin{tabular}{|c|c|c|c|c|c|c|c|c|c|}
\hline \multirow{2}{*}{$\begin{array}{c}\text { Wood } \\
\text { surface } \\
\text { roughness } \\
{[\mu \mathrm{m}]}\end{array}$} & \multicolumn{2}{|c|}{$\begin{array}{c}\text { Thermal } \\
\text { conductivity } \\
{[w / m . k]}\end{array}$} & \multirow{2}{*}{$\begin{array}{l}\text { Wood } \\
\text { species }\end{array}$} & \multirow{2}{*}{ Adhesives } & \multicolumn{5}{|c|}{ Average bonding strengths $\left[\mathrm{N} / \mathrm{mm}^{2}\right]$} \\
\hline & & $\begin{array}{l}\text { nokj } \\
\text { Solid } \\
\text { wood }\end{array}$ & & & Control & $-20{ }^{\circ} \mathrm{C}$ & $60^{\circ} \mathrm{C}$ & $\begin{array}{c}\text { Water } \\
\text { immersion }\end{array}$ & $\begin{array}{l}\text { Water } \\
\text { vapor }\end{array}$ \\
\hline $\mathrm{Ra} 4.86$ & 0.135 & \multirow[b]{2}{*}{0.177} & \multirow{2}{*}{ Uludag Fir } & PVAc-D3 & 7.89 & 5.85 & 6.79 & 2.86 & 5.75 \\
\hline $\begin{array}{c}(0.59) \\
\text { Ry } 6.31\end{array}$ & 0.138 & & & PU- D4 & 6.98 & 5.39 & 6.41 & 4.07 & 5.77 \\
\hline Ra 6.44 & 0.143 & \multirow[b]{2}{*}{0.188} & \multirow[b]{2}{*}{ Chestnut } & PVAc-D3 & 9.34 & 7.01 & 8.54 & 3.37 & 6.88 \\
\hline $\begin{array}{c}(0.4) \\
\text { Ry } 8.59\end{array}$ & 0.164 & & & PU- D4 & 9.24 & 6.66 & 8.22 & 5.38 & 7.04 \\
\hline $\operatorname{Ra} 9.8$ & 0.122 & \multirow{2}{*}{0.174} & \multirow{2}{*}{ Poplar } & PVAc-D3 & 7.70 & 5.61 & 7.27 & 2.52 & 5.47 \\
\hline $\begin{array}{c}(0.10) \\
\text { Ry } 12.59\end{array}$ & 0.152 & & & PU- D4 & 7.01 & 5.46 & 6.91 & 4.75 & 5.61 \\
\hline
\end{tabular}

As shown in Table 2, after the treatment of laminated veneers, the bonding strength was greatly reduced for both adhesives. The highest loss at bonding strengths was determined about $65 \%$ at the Poplar specimens treated with water immersion. In this study, the lowest bonding strength was found in Poplar-PVAc-D3 specimens (2.52 $\mathrm{N} / \mathrm{mm}^{2}$ ) threated with water immersion. Kaygin and Tankut (2008) stated that the lowest bonding strength was due to cell structure of wood and its over porosity structures. Changes in moisture content affect the bonding of laminated veneer panels like in solid wood (Colak et al. 2004). As the moisture of the bonded wood increases, the fibers in the bonding line swell and the adhesive strength decreases. Water-based adhesives degrade at high temperatures and humidity. Altinok (2002) reported that the bonding strength of laminated veneer are decreased at treatments of $80{ }^{\circ} \mathrm{C}$ temperatures.

Roughness is very important for bonded of solid woods. Obtaining smoother surfaces could possibly be related to the changes of 
components in the cell wall (Bakar et al. 2013). In this study, surface roughness values were ranged between $4.86 \mu \mathrm{m}$ and $9.8 \mu \mathrm{m}$. Surface roughness of wood specimens affect the wettability and bonding strength.

The thermal conductivity of the bonded veneer based on all treatments decreased by $30 \%$ when compared to solid wood. It was determined that the veneer bonding treatments decreased thermal conductivity. Besides bonding veneer with PVAc-D3 had a lower thermal conductivity value than of PUD4 (decreased by up to $20 \%$ ). Besides, as it was seen in Table 2, the density determined to affect the thermal conductivity values.

\section{SEM and EDX}

SEM studies were conducted to determine penetration in wood of PU-D4 and PVAc-D3 adhesives. The SEM images of adhesive line are given in Fig. 3, 4a and 4b.

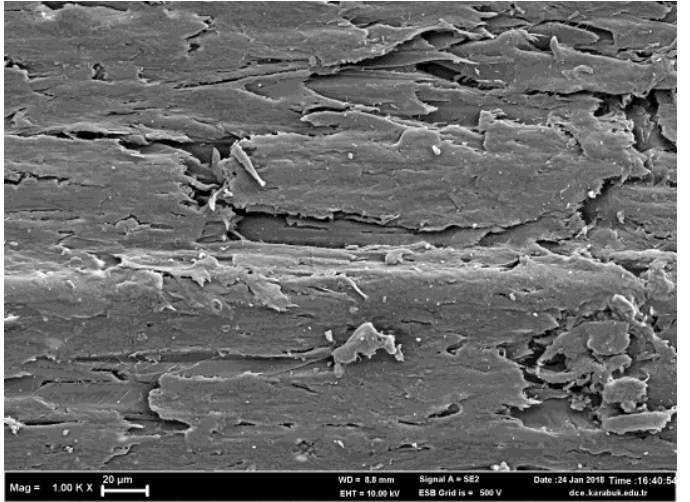

Figure 3. SEM image of chestnut veneer bonded with PVAc-D3.

The adhesive and wood were scanned by SEM and the selected points simultaneously were analyzed by EDX, as shown in Fig. 4c and

$4 d$.
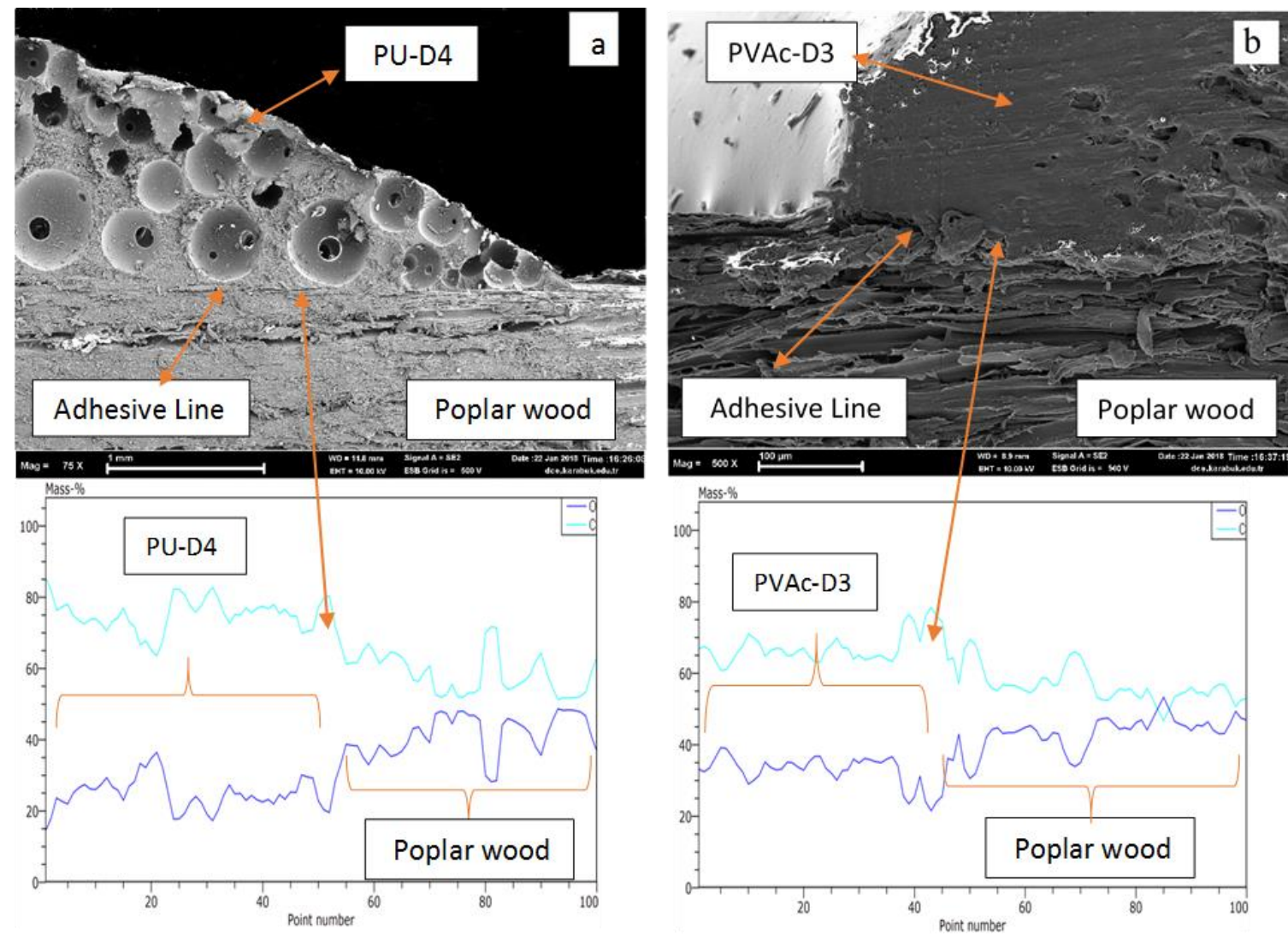

Figure 4. SEM images of Poplar wood specimens show PU-D4 adhesive line (a), PVAc-D3 adhesive line(b). EDX analysis of PU-D4 adhesive line and poplar wood(c), EDX analysis of PVAc-D3 adhesive line and poplar wood (d). 
As seen in Fig. 4, PU-D4 adhesive wetted with a low contact angle in comparison to PVAc-D3 adhesive contact angle. The bonding performance of wood veneer was improved by the interfacial penetration of the adhesive. On the other hand, too much adhesive can deteriorate formation of an adhesive layer and directly influence bonding performance. The final product can be affected by the penetration depth of the adhesive (Gu et al. 2016).

\section{Conclusions}

In this study, the influencing factors on the capability of adhesion in Uludag Fir, Chestnut, and Poplar veneers were investigated. Density of solid wood, surface roughness, thermal conductivity, wettability and treatments on bonding strength were evaluated. The treatments generally reduced the bonding strength of the woods. The adhesion capabilities were directly related to wood density and different treatment factors. The different woods and adhesives used affected wettability. The results clearly indicate that the surface wettability measurements were informative for forming of boundary layers. Wettability properties changed due to surface roughness. When the wettability enhanced, bonding strength increased. The least values in bonding strength were determined for the specimens exposed to water immersion. The highest bonding strengths of the PVAc-D3 adhesives were observed for the control specimens. The treatments of water immersion and water vapor, in particular, led to a decrease in the bonding strength for both types of adhesives. However, PVAc-D3 gave very low adhesion value. The between the treatments of $-20{ }^{\circ} \mathrm{C}$ and $60{ }^{\circ} \mathrm{C}$ was a slight difference in adhesion strength. When considering the wood species used, the Chestnut showed the greatest bonding strength and it was followed by Fir and Poplar. The highest density was obtained in chestnut specimens after water immersion. The lowest density was obtained in Poplar specimens. Thermal conductivity was decreased of the laminated veneer compared with the solid wood. Thermal conductivity of PU-D4 adhesive with bonded veneer was found to be higher than bonded veneer with PVAc-D3.

\section{References}

Altinok, M. (2002). Effect of the Elevated Temperatures on Bonding Performances of Glued Wood Joints. Journal of Polytechnic, 5(4), 341-345.

ASTM C 1113-99 (2004). Standard Test Method for Thermal Conductivity of Refractories by Hot Wire (Platinum Resistance Thermometer Technique). ASTM International; West Conshohocken, USA.

Aydin, I., Colak, S., Colakoglu, G. and Salih, E, (2004). A comparative study on some physical and mechanical properties of laminated veneer lumber (LVL) produced from Beech (Fagus orientalis L.) and Eucalyptus (Eucalyptus camaldulensis Dehn.) veneers. European Journal of Wood and Wood Products, 62(3), 218220.

Bakar, B.F.A., Hiziroglu, S., and Tahir, P.M. (2013). Properties of some thermally modified wood species. Materials \& Design, 43, 348-355.

BS EN 205 (1991). Test methods for wood adhesives for non-structural aplications: determination of tensile shear strength of Lap Joints. British Standarts, England.

Buyuksari, U., Akbulut, T., Guler, C. and As, N. (2011). Wettability and surface roughness of natural and plantation-grown narrow-leaved ash (Fraxinus angustifolia Vahl.) wood. BioResources, 6(4), 47214730.

Candan, Z., Hiziroglu, S., and McDonald, A.G. (2010). Surface quality of thermally compressed Douglas fir veneer. Materials \& Design, 31(7), 3574-3577.

Colak, S., Aydin, I., Demirkir, C. and Colakoglu, G. (2004). Some technological properties of laminated veneer lumber manufactured from pine (Pinus sylvestris L.) veneers with melamine added-UF resins. Turkish Journal of Agriculture and Forestry, 28(2), 109-113.

Dundar, T., Akbulut, T., and Korkut, S. (2008). The effects of some manufacturing factors on surface roughness of sliced Makore (Tieghemella heckelii Pierre Ex A. Chev.) and rotarycut beech (Fagus orientalis L.) veneers. Building and Environment, 43(4), 469474. 
Frihart, C.R. (2005). Handbook of wood chemistry and wood composites. Chapter 9: Wood adhesion and adhesives. CRC Press, 215-278.

Gavrilovic-Grmusa, I., Dunky, M., Miljkovic, J. and Djiporovic-Momcilovic, M. (2012). Influence of the viscosity of UF resins on the radial and tangential penetration into poplar wood and on the shear strength of adhesive joints. Holzforschung, 66(7), 849-856.

$\mathrm{Gu}$ H.M. and Zink-Sharp A. (2005). Geometric model for softwood transverse thermal conductivity. Part 1. Wood and Fiber Science, 37 (4), 699-711.

$\mathrm{Gu}, \mathrm{R} ., \mathrm{Mu}, \mathrm{B}$. and Yang, Y. (2016). Bond Performance and Structural Characterization of Polysaccharide Wood Adhesive Made from Konjac Glucomannan / Chitosan / Polyvinyl Alcohol. BioResources, 11(4), 8166-8177.

Gardner, D. J., Generalla, N. C., Gunnells, D. W., \& Wolcott, M. P. (1991). Dynamic wettability of wood. Langmuir, 7(11), 2498-2502.

Kamala, B.S., Kumar, P., Rao, R.V. and Sharma, S.N, (1999). Performance test of laminated veneer lumber (LVL) from rubber wood for different physical and mechanical properties. European Journal of Wood and Wood Products, 57(2), 114116.

Kamke, F.,A., Lee, J.,N. (2007). Adhesive Penetration In Wood A Review. Wood and Fiber Science, 39(2), 205 - 220.

Kaya, A, (1977). Tutkallar ve Tutkallama Makinaları. Ankara, 1-14.

Kaygin, B., Tankut, A.N. (2008). Comparison of bonding strengths of the sapwoods and heartwoods of tree species used in wooden shipboard building. African Journal of Biotechnology, 7(24), 4620-4627.

Kilic, Y., Colak, M., Baysal, E. and Burdurlu, E. (2006). An investigation of some physical and mechanical properties of laminated veneer lumber manufactured from black alder (Alnus glutinosa) glued with polyvinyl acetate and polyurethane adhesives. Forest Products Journal, 56(9), 56.

Omaç, F., Ozyurek, D., Erer, M. (2017). Investigation of the Wetting Properties of
Ternary Lead-Free Solder Alloys on Copper Substrate "Acta Phy. Polonica A, 131, 1, 165-167.

Selbo, M.L. (1975). Adhesive bonding of wood. US Department of Agriculture.

Shi, S.Q. and Gardner, D.J. (2001). Dynamic adhesive wettability of wood. Wood and Fiber Science, 33(1), 58-68.

Sogutlu, C. (2017). Determination of the effect of surface roughness on the bonding strength of wooden materials. BioResources, 12(1), 1417-1429.

Sulaiman, O., Salim, N., Hashim, R., Yusof, L.H.M., Razak, W., Yunus, N.Y.M., Hashim, W.S. and Azmy, M.H (2009). Evaluation on the suitability of some adhesives for laminated veneer lumber from oil palm trunks. Materials \& Design, 30(9), 3572-3580.

TS 2471 (1976). Wood-determination of moisture content for physical and mechanical tests. Institute of Turkish Standards, Ankara, TURKEY.

TS 2472 (1976). Wood-determination of density for physical and mechanical tests. Institute of Turkish Standards, Ankara, TURKEY.

Uysal, B. and Kurt. S, (2005). Dimensional stability of laminated veneer lumbers manufactured by using different adhesives after the steam test. Gazi University Journal of Science, 18(4), 681-691.

Wang, S., Zhang, Y., \& Xing, C. (2007). Effect of drying method on the surface wettability of wood strands. European Journal of Wood and Wood Products, 65(6), 437-442.

Yorur, H., Kurt, Ş., Uysal B, 2014. Bonding strength of oak with different adhesives after humid-water-heat tests. Journal of Adhesion Science and Technology, 28(7), 690-701.

Yorur, H., Erer, A.M., Oğuz, S. (2017). Effect of Surface Roughness on Wettability of Adhesive on Wood Substrates. 3rd International Conference on Science, Ecology and Technology.

Zhao, M. H., Chen, X. P., \& Wang, Q. (2014). Wetting failure of hydrophilic surfaces promoted by surface roughness. Scientific Reports, 4, 537. 
